\title{
The Effects of Some External Management Factors on the Nitrogen Composition of Cattle Manure on Smallholder Farms
}

\author{
H. A. Markewich, ${ }^{1}$ A. N. Pell, ${ }^{2}$ D. M. Mbugua, ${ }^{3}$ D. J. R. Cherney, ${ }^{1}$ \\ H. M. van Es, ${ }^{3}$ and J. Lehmann ${ }^{3}$ \\ ${ }^{1}$ Department of Animal Science, Cornell University, 149 Morrison Hall, Ithaca, NY 14853, USA \\ ${ }^{2}$ Department of Animal Science, Cornell University, 115 Day Hall, Ithaca, NY 14853, USA \\ ${ }^{3}$ Department of Crop and Soil Sciences, Cornell University, 235 Bradfield Hall, Ithaca, NY 14853, USA
}

Correspondence should be addressed to H. A. Markewich, hamarkewich@gmail.com

Received 16 November 2011; Accepted 12 March 2012

Academic Editor: Dexter B. Watts

Copyright (c) 2012 H. A. Markewich et al. This is an open access article distributed under the Creative Commons Attribution License, which permits unrestricted use, distribution, and reproduction in any medium, provided the original work is properly cited.

Smallholder farmers in Kenya collect manure from confined cattle housing termed zero-grazing units. Zero-grazing designs may include urine collection, though the effectiveness of these designs in improving manure $\mathrm{N}$ content has not been established. The manure-urine mixtures produced in these units were simulated to determine urine effects on manure $\mathrm{N}$ composition. Manure and manure-urine mixtures were stored for 120 days during dry and rainy seasons in Kenya. Manure-urine mixtures leached $26 \%$ of their mineral $\mathrm{N}$ content during the dry season, but only $12 \%$ during the rainy season. After storage, manure-urine mixtures had less organic- $\mathrm{N}$ and fiber- $\mathrm{N}$ than manure alone during the dry season $(P<0.01)$, but not during the rainy season. Results suggest that the effect of cattle urine on manure $\mathrm{N}$ composition is greater during dry seasons than rainy. Manure should not be stored more than 30 days to minimize $\mathrm{N}$ loss to leaching. Farmers may take steps to reduce $\mathrm{N}$ loss by controlling leaching and protecting manure from rainfall.

\section{Introduction}

Smallholder farmers in Kenya who confine their livestock in zero-grazing units collect and store manure for use as a soil amendment during the growing seasons [1]. The design of zero-grazing units may allow for the collection and preservation of some of the cattle urine. A survey of 60 smallholders in the Kenyan highlands reported that more than half of the farms used zero-grazing units with sloped floors and manure storage piles just outside the animal confinement area at the base of the sloped floor [1]. Farmers perceived that manure decomposition speeds up when manure and urine are mixed. Liquids from the zero-grazing unit floor drained into the manure storage pile. Less than $10 \%$ of farms used designs that allowed direct urine collection such as channels to transfer liquid from the zero-grazing unit floor into a reservoir just outside of the confinement area [1]. The animal housing on the remaining farms had no design attributes to conserve urine. The liquid from the floor of the animal confinement area was either absorbed by bedding and feed refusals on the floor of the zero-grazing unit, or soaked into the soil $[1,2]$. Whether the urine-conserving zero-grazing unit designs actually increased manure $\mathrm{N}$ content was not established. The designs may not prevent urinary $\mathrm{N}$ losses via volatilization $[1,2]$.

The $\mathrm{N}$ retention efficiency of zero-grazing systems is poor. More than $36 \%$ of $\mathrm{N}$ in a mixture of manure and urine may be lost between excretion and the end of storage. Urinary-N losses are greater when no refusals to absorb the urine are on the floor of the zero-grazing unit. Manure and urine $\mathrm{N}$ may be lost via leaching when the dirt floors of the zero-grazing units are cleaned out only a few times each year [3].

To determine whether the presence of urine increased manure $\mathrm{N}$ content, experiments were conducted with manure-urine mixtures similar to those produced on farms 


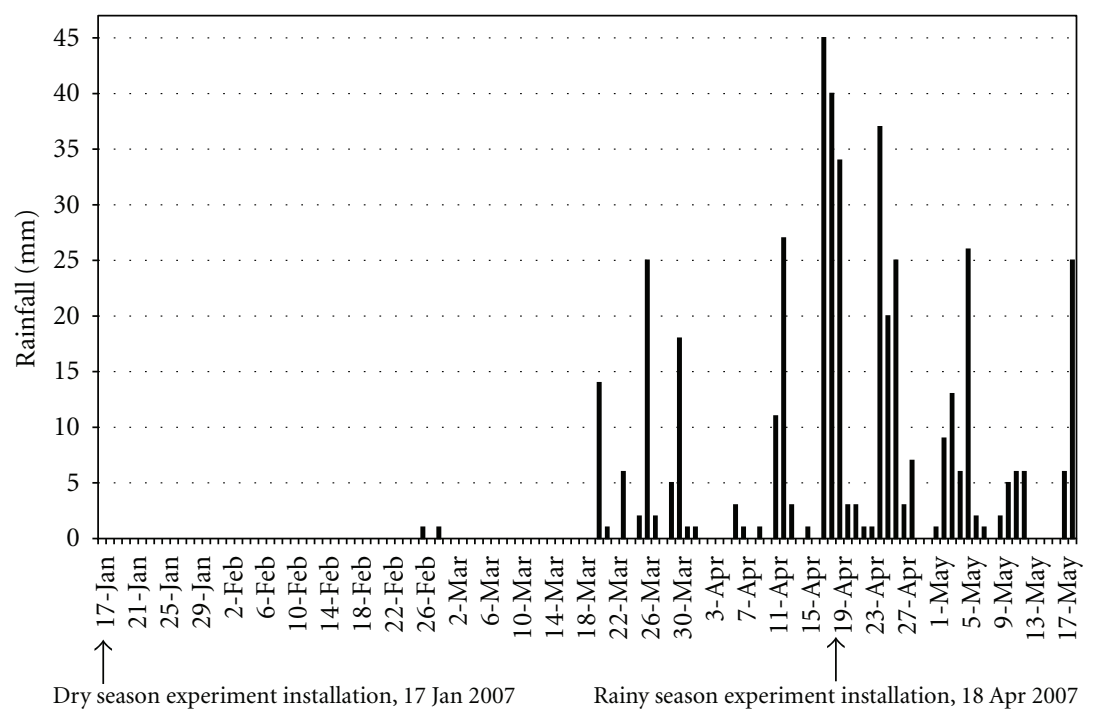

FIGURE 1: Rainfall at the experiment site, Kenya Agricultural Research Institute. Dry season experiment duration: 17 January to 01 June 2007. Rainy season experiment duration: 18 April to 18 May 2007.

with zero-grazing units designed to drain urine into the manure storage piles. In addition to total manure $\mathrm{N}$ content, it is important to consider the patterns of transformation of nitrogenous compounds in manure that occur during storage. One objective of this study was to examine the changes in specific manure $\mathrm{N}$ fractions resulting from inclusion of urine in manure storage systems. It was hypothesized that most $\mathrm{N}$ losses from stored manure occur within the first month of storage. In a study of stored beef cattle manure, $\mathrm{N}$ losses of more than $10 \%$ occurred after 42 days of storage [4]. A second hypothesis was that manure with urine contains more mineral $\mathrm{N}$ and less fiber- $\mathrm{N}$ and lignin$\mathrm{N}$ than manure without urine. Urine is a major source of $\mathrm{N}$ in stored manure [5], so stored manure with urine may not be $\mathrm{N}$-limited, allowing manure microbes to degrade the fibrous manure materials more rapidly. The third hypothesis was that manure mixed with urine leaches more mineral $\mathrm{N}$ than manure without urine. Large losses of urinary $\mathrm{N}$ via leaching and volatilization may occur from manure before its application to soil [6]. Finally, it was hypothesized that heavy rainfall increases $\mathrm{N}$ losses from leaching in newly stockpiled manure because the rain saturates the manure and the water-soluble $\mathrm{N}$ compounds in fresh manure leach from the manure and are not recovered. The effects of season on manure composition and leaching were investigated by starting one experiment during the dry season and one during the rainy season.

\section{Materials and Methods}

2.1. Experimental Design. Manure from two different farms in the Embu area was used to demonstrate the effects of farm and cattle diet management on manure quality. The larger farm maintained a milking herd of approximately 20 cows. The smaller farm milked 4 Holstein-Freisian cattles. The cattles on both farms were fed by the cut-and-carry method, but the cattle of the larger farm were fed energy concentrates and Napier grass (Pennisetum purpureum), a relatively high protein forage, more regularly. That the manure differed in terms of total $\mathrm{N}$ and organic matter (OM) content was established prior to the start of the dry season experiment to establish the effects of different management regimes on manure composition. Based on the initial manure composition and the management styles of the farms, the larger farm was designated the better-managed farm and the smaller farm the less well-managed farm. Based on this distinction in management quality, manure from the smaller farm will be referred to as "Low quality" and manure from the larger farm will be referred to as "Medium quality" from this point forward. The cattle urine used in the manure storage experiments was collected from the milking herds of both farms and mixed before being used in the experiment. The urine collection lasted approximately 10 days before the start of the dry season experiment and the start of the rainy season experiment. The urine was stored at $4^{\circ} \mathrm{C}$ before the beginning of each experiment. At the start of each experiment, samples of the urine were acidified to $\mathrm{pH}<2.5$ using concentrated $\mathrm{H}_{2} \mathrm{SO}_{4}$ to prevent $\mathrm{NH}_{3}$ volatilization by microbes [7]. Before $\mathrm{NH}_{4}-\mathrm{N}$ analysis, samples were stored at $-20^{\circ} \mathrm{C}$.

Two manure storage experiments were conducted, the first beginning in the dry season and carried out for 120 days, and the second beginning early in the long rainy season, ending after 30 days. The two experiments were designed to demonstrate the effects of rainfall on newly established manure storage systems.

The dry season manure storage experiment was conducted from January through June 2007 at the Embu office of the Kenya Agricultural Research Institute in Embu, Eastern Province, Kenya. Mid-January usually marks the beginning of the dry season in Embu, so the experiment was started on January 17, 2007. The installation of the dry season experiment marked the beginning of a 2-month period of very dry weather (Figure 1 ). 
Five-liter plastic buckets were modified to collect leachate from the manure. The bottom of each bucket was removed and replaced with a circular piece of stainless steel 50-mesh screen with square apertures of $279 \mu$ on a side. Each of the 120 buckets was assigned to one of four treatments and placed in one of four adjacent tables in a spatially balanced complete block design to ensure spatial homogeneity in the experiment [8]. A standard funnel-graduated cylinder rain gauge was positioned at the center of the tables and rainfall was measured daily. Three replicates of each treatment were incubated. On a fresh weight $(\mathrm{FW})$ basis, $4.8 \mathrm{~kg}$ of manure was added to each bucket. A volume of $1.4 \mathrm{~L}$ of urine was added to half of the buckets, representing the daily urine volume-to-fecal mass excretion ratio of cattle in water-constrained environments [9]. The urine $\mathrm{NH}_{4}$ $\mathrm{N}$ concentration was $0.03 \mathrm{M}$. Three buckets from each treatment were randomly selected for destructive sampling after $6,12,18,24,30,50,70,90$, and 120 days of incubation. After sampling, subsamples of the manure were immediately stored at $-20^{\circ} \mathrm{C}$.

The rainy season manure storage experiment, to assess the effects of rainfall on newly installed manure storage units, was installed on April 18, 2007. A preliminary period of ten days of moderate precipitation preceded the onset of the long rainy period in mid-April (Figure 1).

The goal of this experiment was to demonstrate the response of newly stockpiled manure to heavy rainfall. The design of the experiment was similar to that of the dry season experiment. Each of 60 buckets was assigned to one of the four treatments in a randomized complete block design. Three replicates of each treatment type were incubated. An initial mass of $4.1 \mathrm{~kg}$ (FW basis) of manure was added to each bucket. This initial manure mass differed from the mass used in the dry season experiment because the manure for this study had a greater water content. The manure for the rainy season study was collected early in the long rainy season. The rains dampened manure in the cattle pens before it was collected. An initial volume of $1.2 \mathrm{~L}$ of urine was added to half of the buckets, to represent the daily urine volume-to-fecal mass excretion ratio of cattle in water-constrained environments [9]. The $\mathrm{NH}_{4}-\mathrm{N}$ concentration of the urine was $0.15 \mathrm{M}$. The higher $\mathrm{NH}_{4}-\mathrm{N}$ concentration of the rainy season urine likely was because cattle were fed more high-protein forages such as Napier grass during the rainy season than during the dry season. Three buckets of each treatment were sampled destructively after $6,12,18,24$, and 30 days of incubation.

For both the rainy and dry season experiments, leachates were collected through a plastic funnel attached to the mesh bottom of each bucket into a $60 \mathrm{~mL}$ bottle containing $1 \mathrm{~mL}$ concentrated $\mathrm{H}_{2} \mathrm{SO}_{4}$. The acid immediately lowered the leachate $\mathrm{pH}$ to less than 2.5 upon entering the bottle in order to check the degradation of organic and inorganic- $\mathrm{N}$ by microbes [7]. The leachate collection bottles were replaced when full and upon the destructive sampling of each bucket. The mass and volume of the leachate collected were recorded. Leachates for each individual bucket were composited by date: after $6,12,18,24,30,50,70,90$, and 120 days of storage for the dry season experiment and after $6,12,18,24$, and 30 days of storage for the rainy season experiment.
2.2. Chemical Analyses. One gram of each frozen subsample was thawed and extracted in $50 \mathrm{~mL}$ water for $30 \mathrm{~min}$ using an orbital shaker set to $180 \mathrm{rpm}$. The $\mathrm{NH}_{4}-\mathrm{N}$ contents of the extracts were measured using a colorimetric method [10] in the soil analysis laboratories of the Kenya Agricultural Research Institute in Embu, Kenya and of the World Agroforestry Centre Headquarters in Nairobi, Kenya.

Aliquots of the manure samples were dried at $\leq 60^{\circ} \mathrm{C}$ and ground to pass a $1 \mathrm{~mm}$ screen in preparation for analysis. The samples were analyzed at the Dairy One Laboratories, Ithaca New York, USA for total N by the Kjeldahl method [11] and for neutral detergent insoluble N (NDIN) and acid detergent insoluble $\mathrm{N}$ (ADIN) [12]. It was assumed that all mineral $\mathrm{N}$ volatilized from the manure during the drying process, so the measurement of total $\mathrm{N}$ by the Kjeldahl method was a direct measurement of organic $\mathrm{N}$ for the dried samples.

2.3. Statistical Analyses. The dry and rainy experiments were designed as multi-factor models with fixed effects where the fixed factors were manure quality, urine presence, and days in storage. All possible interactions between the fixed effects were tested. The absolute concentration data were analyzed using the PROC MIXED procedure of the SAS software [13]. Comparisons were made using the Student's $t$-test.

Using the PROC NLIN procedure of the SAS software [13], exponential decay models were developed to describe the $\mathrm{NH}_{4}-\mathrm{N}$, total organic $\mathrm{N}, \mathrm{NDIN}$, and ADIN the manure in storage over time. Decay models with one exponential term were fitted to the data using the equation $Y=\alpha e^{k x}$, where $Y$ represents the $\mathrm{NH}_{4}-\mathrm{N}$, organic $\mathrm{N}, \mathrm{NDIN}$, or ADIN content of the manure, $x$ represents the number of days the manure was incubated in storage, and $k$ represents the rate of decay of the $\mathrm{NH}_{4}-\mathrm{N}$, organic $\mathrm{N}, \mathrm{NDIN}$, or ADIN in the manure. Regression of the data using double exponential decay equations failed to converge.

The PROC NLIN procedure of the SAS software was used to develop logarithmic models describing the cumulative $\mathrm{NH}_{4}-\mathrm{N}$ losses from manure in storage via leaching [13]. Logarithmic models with one term were fitted to the data using the equation $Y=k \ln (x)$, where $Y$ represents the leached $\mathrm{NH}_{4}-\mathrm{N}, x$ represents the number of days the manure was incubated in storage, and $k$ represents the rate of accumulation of the $\mathrm{NH}_{4}-\mathrm{N}$ leached from the manure. Regression of the data using log-log equations failed to converge.

\section{Results}

Results of the mixed model analyses for the dry season experiment appear in Tables 1, 2, and 3. The mixed model analyses results for the rainy season experiment appear in Tables 4 and 5.

Cattle feces contain essentially no urea $[14,15]$. Cattle urine contains both urea and $\mathrm{NH}_{4}$. However, since the fecal $\mathrm{pH}$ was approximately $\mathrm{pH} 8$, it is assumed that the urea of the urine immediately underwent hydrolysis to produce $\mathrm{NH}_{4}$ when the urine and manure were mixed. In this study, $\mathrm{NH}_{4}-$ $\mathrm{N}$ represents mineral $\mathrm{N}$. 
TABLE 1: ANOVA results for dry matter (DM) mass remaining in manure in storage in the dry season experiment, as a percent of the initial manure DM mass and for $\mathrm{N}$ content (DM basis) of manure in storage in the dry season experiment, as a percent of the initial manure $\mathrm{N}$ content. Fixed effects are the manure quality (Medium versus Low quality), the presence or absence of urine in the manure, and the number of days the manure was incubated $(0,6,12,18,24,30,50,70,90$, or 120 days). Terms for the interaction between fixed effects are denoted by fixed effects terms separated by an asterisk $(*)$. DF represents the degrees of freedom of the test.

\begin{tabular}{|c|c|c|c|c|c|}
\hline \multirow[b]{2}{*}{ Effect } & \multicolumn{5}{|c|}{$P$-value } \\
\hline & $\mathrm{DF}$ & $\begin{array}{c}\text { DM mass } \\
(\% \text { of initial DM mass })\end{array}$ & $\begin{array}{c}\mathrm{N} \\
(\% \text { of } \mathrm{DM})\end{array}$ & $\begin{array}{c}\text { ADIN } \\
(\% \text { of DM })\end{array}$ & $\begin{array}{c}\text { NDIN } \\
(\% \text { of DM })\end{array}$ \\
\hline $\begin{array}{l}\text { Medium versus Low quality manure } \\
{[\mathrm{A}]}\end{array}$ & 1 & $<0.0001$ & 0.0218 & $<0.0001$ & $<0.0001$ \\
\hline Urine added versus no urine $[\mathrm{B}]$ & 1 & $<0.0001$ & 0.0024 & 0.0303 & 0.0052 \\
\hline Days in storage $[\mathrm{C}]$ & 8 & $<0.0001$ & $<0.0001$ & $<0.0001$ & $<0.0001$ \\
\hline $\mathrm{A}^{*} \mathrm{~B}$ & 1 & 0.8085 & 0.0348 & 0.0875 & 0.0119 \\
\hline $\mathrm{A}^{*} \mathrm{C}$ & 8 & 0.0058 & 0.0798 & 0.1258 & 0.1166 \\
\hline $\mathrm{B}^{*} \mathrm{C}$ & 8 & 0.0749 & 0.0464 & 0.0092 & 0.0029 \\
\hline $\mathrm{A}^{*} \mathrm{~B} * \mathrm{C}$ & 8 & 0.2125 & 0.8771 & 0.8403 & 0.3715 \\
\hline
\end{tabular}

TABLE 2: ANOVA results for $\mathrm{NH}_{4}-\mathrm{N}$ concentration (mg $\mathrm{NH}_{4}$ $\mathrm{N} / \mathrm{kg}$ manure, DM basis) of manure in storage in the dry season experiment. Fixed effects are the manure quality (Medium versus Low quality), the presence or absence of urine in the manure, and the number of days the manure was incubated $(0,6,12,18,24,30$, $50,70,90$, or 120 days). Terms for the interaction between fixed effects are denoted by fixed effects terms separated by an asterisk $(*)$. DF represents the degrees of freedom of the test.

\begin{tabular}{|c|c|c|}
\hline \multirow[b]{2}{*}{ Effect } & \multicolumn{2}{|r|}{$P$-value } \\
\hline & DF & $\begin{array}{c}\mathrm{NH}_{4}-\mathrm{N} \\
\text { (mg/kg manure) }\end{array}$ \\
\hline $\begin{array}{l}\text { Medium versus Low quality manure } \\
\text { [A] }\end{array}$ & 1 & 0.0147 \\
\hline Urine added versus no urine $[\mathrm{B}]$ & 1 & 0.0079 \\
\hline Days in storage $[\mathrm{C}]$ & 9 & $<0.0001$ \\
\hline$A^{*} B$ & 1 & 0.7994 \\
\hline $\mathrm{A}^{*} \mathrm{C}$ & 8 & 0.5932 \\
\hline $\mathrm{B}^{*} \mathrm{C}$ & 9 & 0.0199 \\
\hline $\mathrm{A}^{*} \mathrm{~B} * \mathrm{C}$ & 8 & 0.0453 \\
\hline
\end{tabular}

Figure 2 shows the $\mathrm{NH}_{4}-\mathrm{N}$ dynamics in manure of the dry season experiments. After 30 days of storage, the $\mathrm{NH}_{4}$ $\mathrm{N}$ concentration of manure alone ranged from 156 to $241 \mathrm{mg} \mathrm{NH} 4-\mathrm{N}$ per $\mathrm{kg}$ of manure (DM basis) in individual treatments. The $\mathrm{NH}_{4}-\mathrm{N}$ concentration of urine-amended manure ranged from 372 to $375 \mathrm{mg} \mathrm{NH}_{4}-\mathrm{N}$ per kg of manure (DM basis) in individual treatments after 30 days of storage. The manure source had no effect on manure $\mathrm{NH}_{4}-\mathrm{N}$ after 30 days or 120 days $(\alpha=0.05$, Figure 2$)$. In the dry season experiment, manure alone contained less $\mathrm{NH}_{4}-\mathrm{N}$ per $\mathrm{kg}$ of manure (DM basis) than the treatments with urine after 30 days of storage $(P<0.04)$.

Exponential decay models to describe the $\mathrm{NH}_{4}-\mathrm{N}$ dynamics of the Medium quality manure and Low quality manure in the rainy season experiment using two exponential terms did not converge. Exponential models with one exponential term to describe $\mathrm{NH}_{4}-\mathrm{N}$ dynamics appear in Figure 3.
TABle 3: ANOVA results for $\mathrm{NH}_{4}-\mathrm{N}$ content (mg $\mathrm{NH}_{4}-\mathrm{N}$ per manure storage unit) of leachate collected from manure in storage in the dry season experiment. Fixed effects are the manure quality (Medium versus Low quality), the presence or absence of urine in the manure, and the number of days the manure was incubated $(0$, $6,12,18,24,30,50,70,90$, or 120 days). Terms for the interaction between fixed effects are denoted by fixed effects terms separated by an asterisk $\left(^{*}\right)$. DF represents the degrees of freedom of the test.

\begin{tabular}{lcc}
\hline Effect & \multicolumn{2}{c}{$\begin{array}{c}\text {-value } \\
\text { Leachate } \mathrm{NH}_{4}-\mathrm{N} \\
\text { (mg/storage unit) }\end{array}$} \\
\hline Medium versus Low quality manure & 1 & 0.4382 \\
[A] & 1 & 0.0192 \\
Urine added versus no urine [B] & 8 & 0.0281 \\
Days in storage [C] & 1 & 0.9802 \\
$\mathrm{~A}^{*} \mathrm{~B}$ & 8 & 0.9152 \\
$\mathrm{~A}^{*} \mathrm{C}$ & 7 & 0.3538 \\
$\mathrm{~B}^{*} \mathrm{C}$ & 7 & 0.9861 \\
$\mathrm{~A}^{*} \mathrm{~B} * \mathrm{C}$ & &
\end{tabular}

During the early rainy season, forages are more nutritious and digestible which may explain the marked difference in the $\mathrm{NH}_{4}-\mathrm{N}$ concentration of the urine used in the dry season and rainy season experiments. Neither the source of the manure nor the presence of urine in the manure affected the $\mathrm{NH}_{4}-\mathrm{N}$ concentration of the manure in the rainy season experiment ( $\alpha=0.05$, Table 5). Average manure $\mathrm{NH}_{4}-\mathrm{N}$ for all treatments after 30 days of storage during the rainy season was $572 \mathrm{mg}$ per $\mathrm{kg}$ of manure (DM basis).

Figures 4(a)-4(c) show the organic N, NDIN, and ADIN dynamics in manure of the dry season experiment in terms of $\%$ remaining from the total amounts in the fresh manure at the start of the experiment. In terms of absolute content, there was no difference in the manure NDIN or manure ADIN after 30 days in storage $(\alpha=0.05)$, nor was there a difference between the total organic $\mathrm{N}$ content of the medium and low farm manure after 30 days of storage or at 
TABLE 4: ANOVA results for $\mathrm{N}$ content (DM basis) of manure in storage in the rainy season experiment, as a percent of the initial manure $\mathrm{N}$ content, and for $\mathrm{NH}_{4}-\mathrm{N}$ content (mg NH$-\mathrm{N}$ per manure storage unit) of leachate collected from manure in storage in the rainy season experiment. Fixed effects are the manure quality (Medium versus Low quality), the presence or absence of urine in the manure, and the number of days the manure was incubated $(0,6,12,18,24$, or 30 days). Terms for the interaction between fixed effects are denoted by fixed effects terms separated by an asterisk $(*)$. DF represents the degrees of freedom of the test.

\begin{tabular}{|c|c|c|c|c|c|c|}
\hline \multirow[b]{2}{*}{ Effect } & \multicolumn{6}{|c|}{$P$-value } \\
\hline & $\mathrm{DF}$ & $\begin{array}{c}\text { DM mass } \\
\text { (\% of initial DM mass) }\end{array}$ & $\begin{array}{c}\mathrm{N} \\
(\% \text { of DM) }\end{array}$ & $\begin{array}{c}\text { ADIN } \\
(\% \text { of DM })\end{array}$ & $\begin{array}{c}\text { NDIN } \\
(\% \text { of DM })\end{array}$ & $\begin{array}{l}\text { Leachate } \mathrm{NH}_{4}-\mathrm{N} \\
\text { (mg/storage unit) }\end{array}$ \\
\hline Medium versus Low quality [A] & 1 & 0.1037 & $<0.0001$ & $<0.0001$ & $<0.0001$ & $<0.0001$ \\
\hline Urine added versus no urine $[\mathrm{B}]$ & 1 & 0.9842 & 0.1039 & 0.1967 & 0.079 & $<0.0001$ \\
\hline Days in storage $[\mathrm{C}]$ & 4 & 0.0004 & 0.0077 & 0.0314 & 0.2868 & $<0.0001$ \\
\hline$A * B$ & 1 & 0.4727 & 0.009 & 0.4382 & 0.2768 & $<0.0001$ \\
\hline $\mathrm{A}^{*} \mathrm{C}$ & 4 & 0.9315 & 0.932 & 0.8198 & 0.9332 & $<0.0001$ \\
\hline $\mathrm{B}^{*} \mathrm{C}$ & 4 & 0.5561 & 0.922 & 0.9606 & 0.9683 & $<0.0001$ \\
\hline $\mathrm{A}^{*} \mathrm{~B} * \mathrm{C}$ & 4 & 0.7194 & 0.1104 & 0.2577 & 0.435 & $<0.0001$ \\
\hline
\end{tabular}

TABle 5: ANOVA results for $\mathrm{NH}_{4}-\mathrm{N}$ concentration (mg $\mathrm{NH}_{4}$ $\mathrm{N} / \mathrm{kg}$ manure, DM basis) of manure in storage in the rainy season experiment. Fixed effects are the manure quality (Medium versus Low quality), the presence or absence of urine in the manure, and the number of days the manure was incubated $(0,6,12,18,24$, or 30 days). Terms for the interaction between fixed effects are denoted by fixed effects terms separated by an asterisk $(*)$. DF represents the degrees of freedom of the test.

\begin{tabular}{lcc}
\hline Effect & \multicolumn{2}{c}{$\begin{array}{c}P \text {-value } \\
\mathrm{NH}_{4}-\mathrm{N}\end{array}$} \\
& DF & $\begin{array}{c}\text { (mg/kg manure }) \\
\text { Medium versus Low quality manure }\end{array}$ \\
{$[\mathrm{A}]$} & 1 & 0.8389 \\
Urine added versus no urine [B] & 1 & 0.2912 \\
Days in storage [C] & 5 & 0.0473 \\
$\mathrm{~A}^{*} \mathrm{~B}$ & 1 & 0.1899 \\
$\mathrm{~A}^{*} \mathrm{C}$ & 5 & 0.7942 \\
$\mathrm{~B}^{*} \mathrm{C}$ & 5 & 0.6891 \\
$\mathrm{~A}^{*} \mathrm{~B} * \mathrm{C}$ & 5 & 0.904 \\
\hline
\end{tabular}

the end of the experiment $(\alpha=0.05)$. The days in storage had an effect on the organic N, ADIN, and NDIN contents of the dry season manure over the entire experiment $(P<0.0001$, Table 1), but no treatment effects on total organic N, NDIN, or ADIN were observed after 30 days in storage (Figures $4(a)-4(c))$. Single-term exponential decay models for total N, NDIN, and ADIN dynamics in manure appear in Figures 4(a)-4(c). Exponential decay models using two exponential terms to describe total N, NDIN, and ADIN dynamics in the manure failed to converge.

In general, lignin-bound $\mathrm{N}$ is considered to be quite refractory and poorly available for microbial degradation $[16,17]$. Non-fiber bound nitrogenous organic compounds are more readily available for degradation than hemicellulose-bound $\mathrm{N}$, cellulose-bound $\mathrm{N}$, and lignin- $\mathrm{N}$ (represented by NDIN), and cellulose-bound $\mathrm{N}$ and lignin$\mathrm{N}$ (represented by ADIN). The portion of the labile organic $\mathrm{N}$ that is microbial $\mathrm{N}$ can be recycled when a microbe dies and lyses and its cell contents, including nitrogenous compounds, are metabolized by other living microbes. The magnitudes of the $\mathrm{N}$ fractions in manure of the rainy season experiment were not affected by urine amendments $(\alpha=0.05$, Table 4$)$. After 30 days of storage, the Medium quality manure alone contained $9.2 \%$ organic $\mathrm{N}, 4.9 \%$ NDIN, and 3.9\% ADIN (DM basis). The Low quality manure contained $11.0 \%$ organic N, 5.1\% NDIN, and 4.1\% ADIN $(D M$ basis, Figures $5(a)-5(c))$. The source of the manure did affect $\mathrm{N}$ composition $(P<0.0001$ for organic $\mathrm{N}, P<0.0001$ for ADIN, $P<0.0001$ for NDIN) with higher levels of ADIN in the Low quality manure $(P<0.04)$ after 30 days of storage. The time in storage had an effect on the organic $\mathrm{N}(P<$ $0.008)$ and $\operatorname{ADIN}(P<0.04)$ throughout the experiment, but at the end of the rainy season experiment, the total organic $\mathrm{N}$ and ADIN content of the two manures did not differ ( $\alpha=0.05$, Table 4$)$. The length of storage had no effect on NDIN $(\alpha=0.05$, Table 4$)$. Exponential decay models with one exponential term were developed for total N, NDIN, and ADIN dynamics in manure (Figures 5(a)-5(c)). Decay models with two exponential terms did not converge.

Single-term logarithmic rate equations describing cumulative leaching of $\mathrm{NH}_{4}-\mathrm{N}$ from manure in the dry season experiment appear in Figure 6. Logarithmic models with two terms to describe cumulative $\mathrm{NH}_{4}-\mathrm{N}$ leaching failed to converge. From each of the 4 treatments, more than $50 \%$ of the final amount of $\mathrm{NH}_{4}-\mathrm{N}$ loss from the manure via leaching occurred during the first 30 days of storage.

Inclusion of urine significantly increased the amount of $\mathrm{NH}_{4}-\mathrm{N}$ leached from manure in the rainy season experiment $(P<0.0001$, Table 4$)$. Total $\mathrm{NH}_{4}-\mathrm{N}$ losses from urineamended manure in the rainy season experiment were larger than from urine-amended manure in the dry season experiment. Neither the manure source nor the urine treatment affected the amount of $\mathrm{NH}_{4}-\mathrm{N}$ leached during the 30 day storage period ( $\alpha=0.05$; Figure 7 ). The final cumulative leaching loss from urine-amended manure storage units was larger than that from units containing only manure. After 30 days of storage during the rainy season, the urine-amended manure storage units lost an average of $337 \mathrm{mg} \mathrm{NH}_{4}-\mathrm{N}$ and 


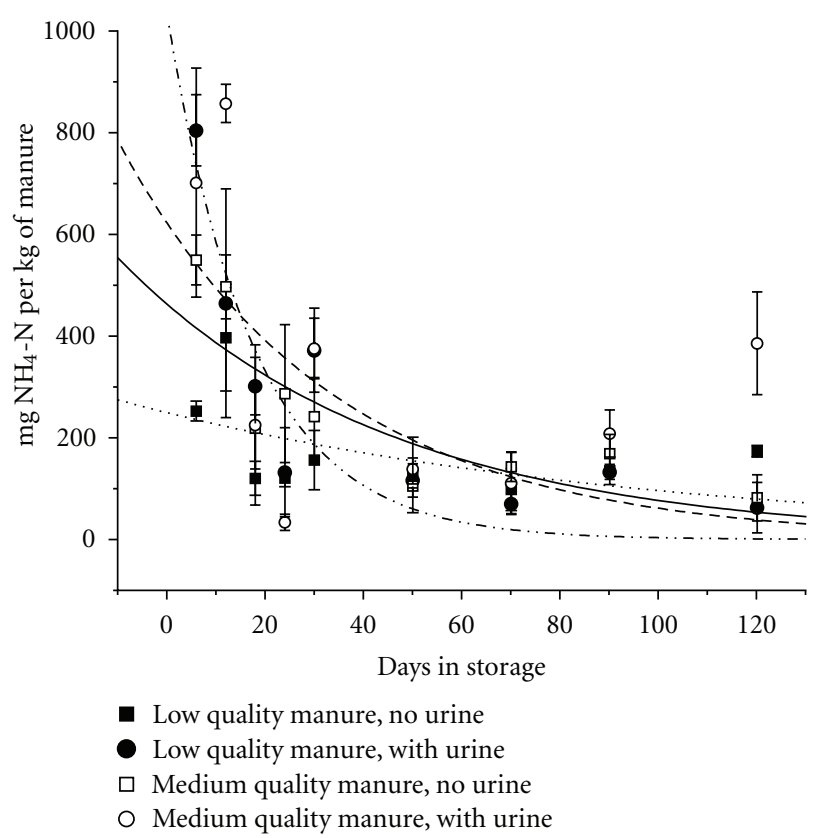

Figure 2: $\mathrm{NH}_{4}-\mathrm{N}$ dynamics in manure of the dry season storage experiment. Error bars represent standard error of the mean values. Continuous lines represent the best-fit regression equations for $\mathrm{NH}_{4}-\mathrm{N}$ dynamics in manure during the dry season experiment. $Y$ represents the amount of $\mathrm{NH}_{4}-\mathrm{N}(\mathrm{mg} / \mathrm{kg}$ manure DM) in the manure. The solid line (-) represents the Medium quality manure, no urine treatment. The dashed line (-- -) represents the urine-amended Medium quality manure treatment. The dotted line $(\cdots)$ represents the Low quality manure, no urine treatment. The dot-dash line $(-\cdots \ldots)$ represents the urine-amended Low quality manure treatment. Medium quality manure, no urine: $Y=$ $462.3 e^{-0.0180 x}, R^{2}=0.807$. Medium quality manure, with urine: $Y=621.8 e^{-0.0232 x}, R^{2}=0.619$. Low quality manure, no urine: $Y=249.1 e^{-0.00955 x}, R^{2}=0.715$. Low quality manure, with urine: $Y=1033.7 e^{-0.0570 x}, R^{2}=0.812$. The rate equations for $\mathrm{NH}_{4}-\mathrm{N}$ dynamics between the manure sources did not differ at significance level $\alpha=0.05$.

the storage units containing manure alone lost an average of $97 \mathrm{mg} \mathrm{NH}_{4}-\mathrm{N}$. These cumulative leaching losses represent up to $12 \%$ of the initial manure $\mathrm{NH}_{4}-\mathrm{N}$ from urine-amended manure and up to $57 \%$ of the initial manure $\mathrm{NH}_{4}-\mathrm{N}$ from manure alone.

After 120 days of storage in the dry season experiment, urine-amended manure lost up to $59 \%$ of its initial DM mass while manure alone lost up to $45 \%$ of the initial DM. These represent mass losses of up to $0.6 \mathrm{~kg}$ DM from urineamended manure and $0.5 \mathrm{~kg}$ DM from manure alone after 120 days of storage. At the end of the rainy season experiment, there were no treatment effects on mass loss $(\alpha=0.05)$.

Figure 2 shows the $\mathrm{NH}_{4}-\mathrm{N}$ dynamics in manure of the dry season experiment. Exponential regression equations with one term to describe the $\mathrm{NH}_{4}-\mathrm{N}$ dynamics were developed using manure data for the dry season experiment (Figure 2). Attempted exponential decay models to describe $\mathrm{NH}_{4}-\mathrm{N}$ dynamics with two exponential terms did not converge. In the dry season experiment, the manure $\mathrm{NH}_{4}-\mathrm{N}$

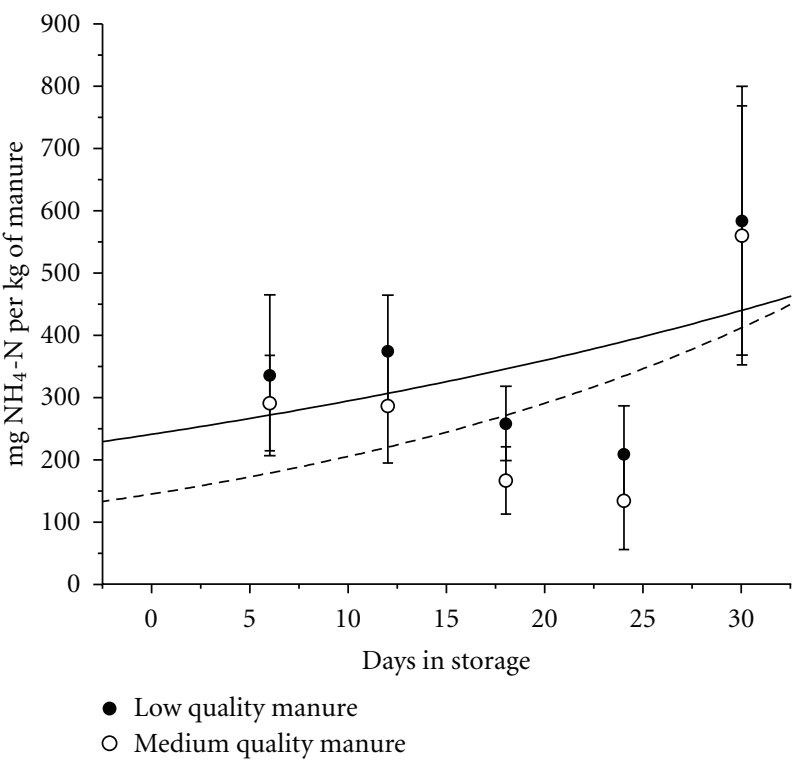

FIGURE 3: $\mathrm{NH}_{4}-\mathrm{N}$ dynamics in manure of the rainy season storage experiment. Error bars represent standard error of the mean values. Continuous lines represent the best-fit regression equations for $\mathrm{NH}_{4}-\mathrm{N}$ dynamics in manure during the dry season experiment. The solid line (-) represents the best-fit regression for the Medium quality manure treatments. The dashed line (---) represents the best-fit regression for the Low quality manure treatments. $Y$ represents the amount of $\mathrm{NH}_{4}-\mathrm{N}(\mathrm{mg} / \mathrm{kg}$ manure $\mathrm{DM})$ in the manure. Medium quality manure: $Y=144.7 e^{0.0349 x}, R^{2}=0.508$. Low quality manure: $Y=240.7 e^{0.0201 x}, R^{2}=0.571$. The rate equations for $\mathrm{NH}_{4}-\mathrm{N}$ dynamics between the manure sources did not differ at significance level $\alpha=0.05$.

dynamics fit an exponential decay pattern (Figure 2). Most of the $\mathrm{NH}_{4}-\mathrm{N}$ loss from the manure occurred during the first 50 days of incubation (Figure 2), before heavy rainfall began at 63 days of incubation (Figure 1). At the end of 120 days of storage in the dry season experiment, manure $\mathrm{NH}_{4}-\mathrm{N}$ fell to less than $200 \mathrm{mg}$ per $\mathrm{kg}$ of manure, with the exception of the urine-amended Medium quality manure. In this treatment, the manure $\mathrm{NH}_{4}-\mathrm{N}$ concentration increased after 50 days in storage. At 120 days of storage, the $\mathrm{NH}_{4}-\mathrm{N}$ concentration of the Medium quality manure amended with urine was nearly $400 \mathrm{mg}$ per $\mathrm{kg}$ of manure (Figure 2). This effect was likely due not to an increase in the pool of $\mathrm{NH}_{4}-\mathrm{N}$ in the manure, but the result of an increase in the manure $\mathrm{NH}_{4}-\mathrm{N}$ concentration as the manure decomposed. As manure decomposes, its $\mathrm{C}$ containing compounds are converted to $\mathrm{CO}_{2}$ and $\mathrm{CH}_{4}$. The loss of $\mathrm{C}$ mass reduces the manure $\mathrm{C}: \mathrm{N}$, and the content of manure $\mathrm{N}$ compounds increase [18].

In the dry season experiment, manure with urine treatments did not contain significantly more $\mathrm{NH}_{4}-\mathrm{N}$ at the end of the 120 day experiment than the treatments with manure alone $(\alpha=0.05)$. The manure $\mathrm{NH}_{4}-\mathrm{N}$ concentration averaged $176 \mathrm{mg} \mathrm{NH} \mathrm{NH}_{4}-\mathrm{N}$ per $\mathrm{kg}$ of manure (DM basis) with a range of 63 to $385 \mathrm{mg} \mathrm{NH} \mathrm{NH}_{4}-\mathrm{N}$ per $\mathrm{kg}$ of manure (DM basis). The manure source had no effect on manure $\mathrm{NH}_{4}-\mathrm{N}$ after 120 days $(\alpha=0.05$, Figure 2). 


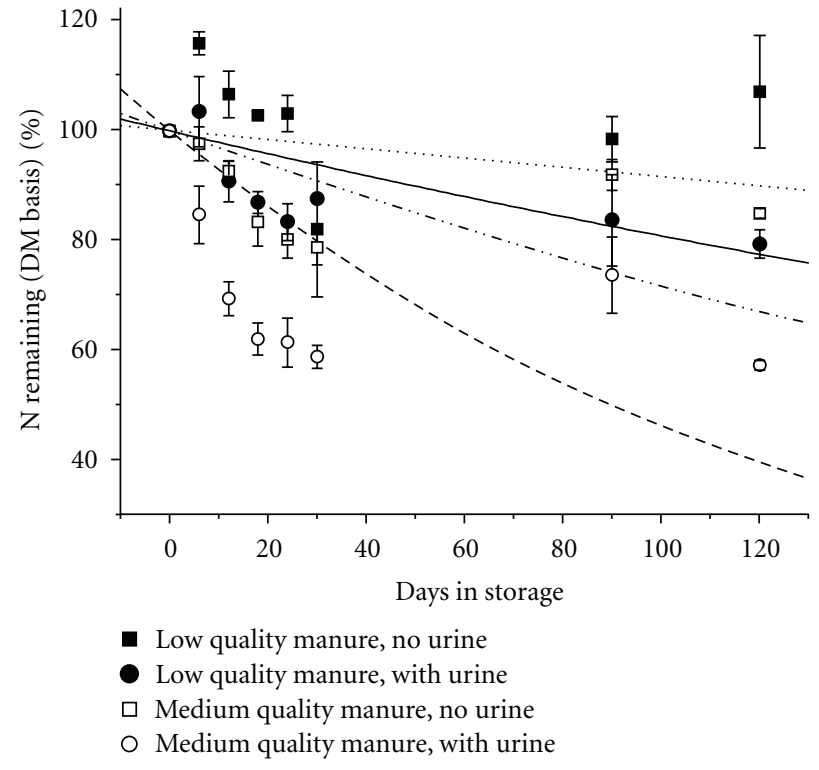

(a)

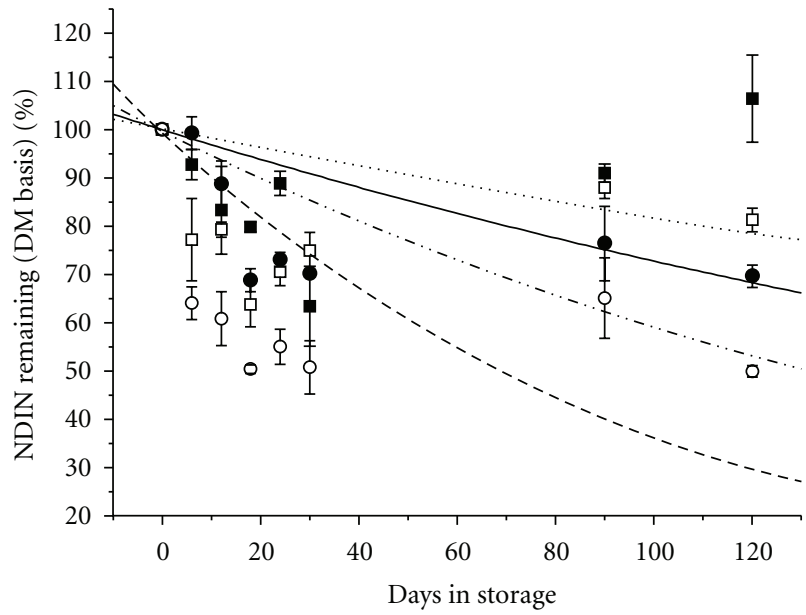

- Low quality manure, no urine

- Low quality manure, with urine

$\square$ Medium quality manure, no urine

○ Medium quality manure, with urine

(b)

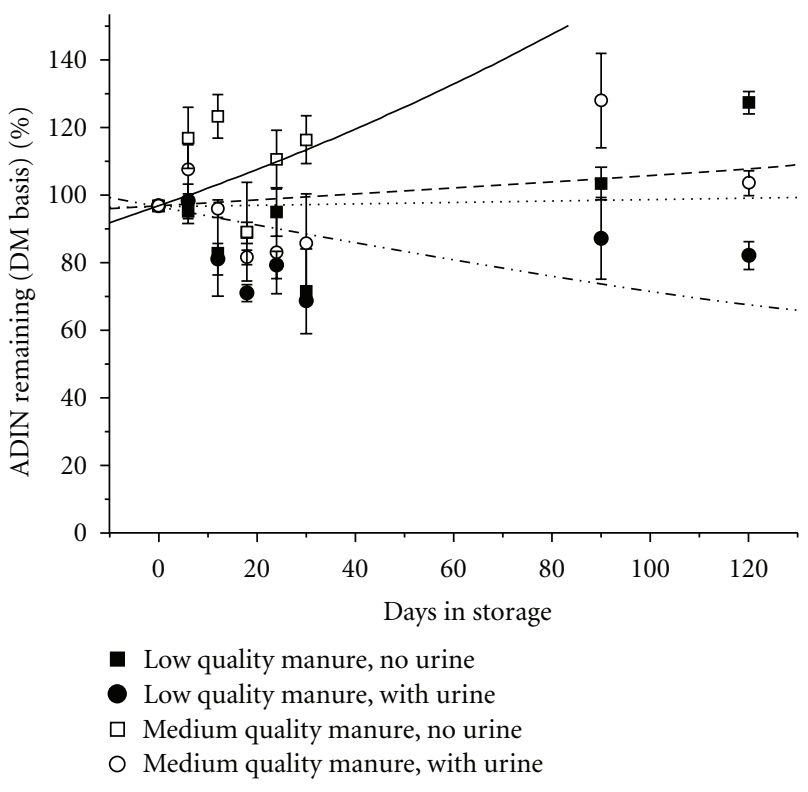

(c)

Figure 4: Total organic N, neutral detergent insoluble N (NDIN), and acid detergent insoluble N (ADIN) dynamics in manure in the dry season experiment (DM basis). Error bars represent standard error of means. Continuous lines represent best-fit regression equations for organic $\mathrm{N}$ dynamics in manure during the dry season experiment. $Y$ represents the amount of organic N, NDIN, or ADIN remaining in the manure (\% of initial content, DM basis). The solid line (-) represents the Medium quality manure, no urine treatment. The dashed line (- - - ) represents the urine-amended Medium quality manure treatment. The dotted line $(\cdots)$ represents the Low quality manure, no urine treatment. The dot-dash line $(-\cdots \ldots)$ represents the urine-amended Low quality manure treatment. (a) Total organic N dynamics (\% N, DM basis). Medium quality manure, no urine: $Y=100 e^{-0.00213 x}, R^{2}=0.978$. Medium quality manure, with urine: $Y=100 e^{-0.00768 x}, R^{2}=0.916$. Low quality manure, no urine: $Y=100 e^{-0.00087 x}, R^{2}=0.971$. Low quality manure, with urine: $Y=100 e^{-0.00327 x}, R^{2}=0.982$. The rate equations for NDIN dynamics between the four treatments did not differ at significance level $\alpha=0.05$. (b) NDIN dynamics (\%NDIN, DM basis). Medium quality manure, no urine: $Y=100 e^{-0.00318 x}, R^{2}=0.940$. Medium quality manure, with urine: $Y=100 e^{-0.00994 x}, R^{2}=0.823$. Low quality manure, no urine: $Y=100 e^{-0.00202 x}, R^{2}=0.945$. Low quality manure, with urine: $Y=100 e^{-0.00529 x}, R^{2}=0.961$. The rate equations for organic $\mathrm{N}$ dynamics between the four treatments did not differ at significance level $\alpha=0.05$. (c) ADIN dynamics (\%ADIN, DM basis). Medium quality manure, no urine: $Y=100 e^{0.00528 x}, R^{2}=0.976$. Medium quality manure, with urine: $Y=100 e^{0.000918 x}, R^{2}=0.970$. Low quality manure, no urine: $Y=100 e^{0.000219 x}, R^{2}=0.951$. Low quality manure, with urine: $Y=100 e^{-0.00288 x}, R^{2}=0.964$. Rate constants for ADIN dynamics in manure with no urine added differed between the manure sources $(P<0.0001)$. No difference was observed in the urine treatments $(\alpha=0.05)$. 


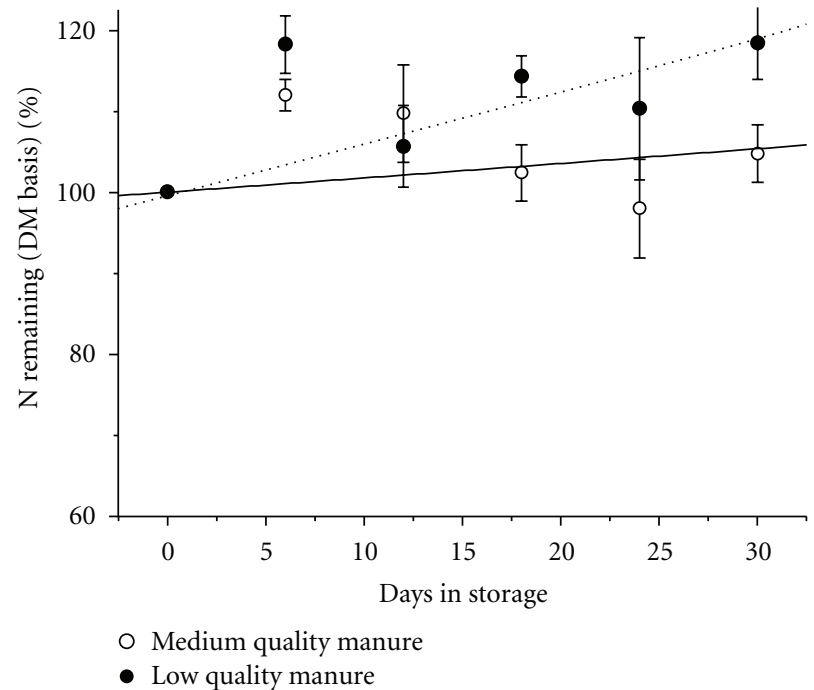

(a)

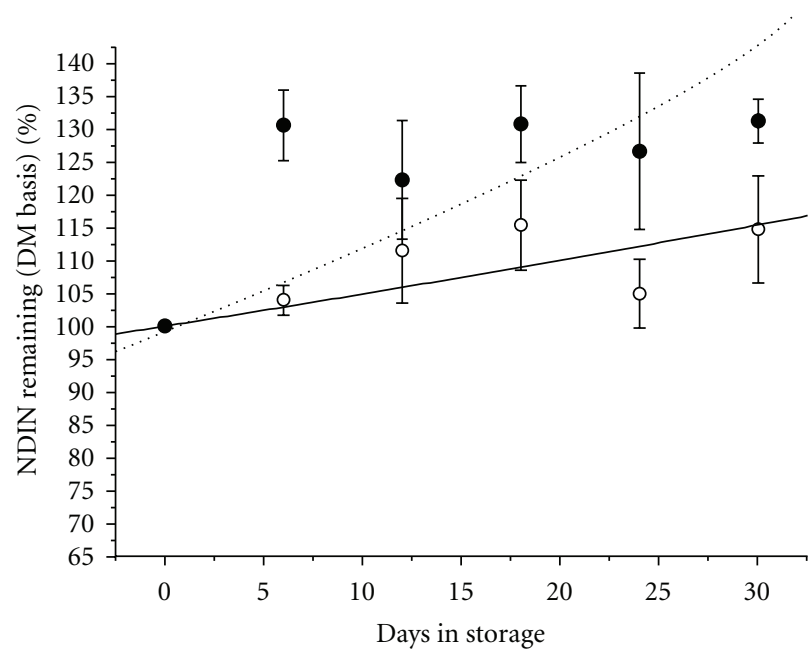

- Medium quality manure

- Low quality manure

(b)

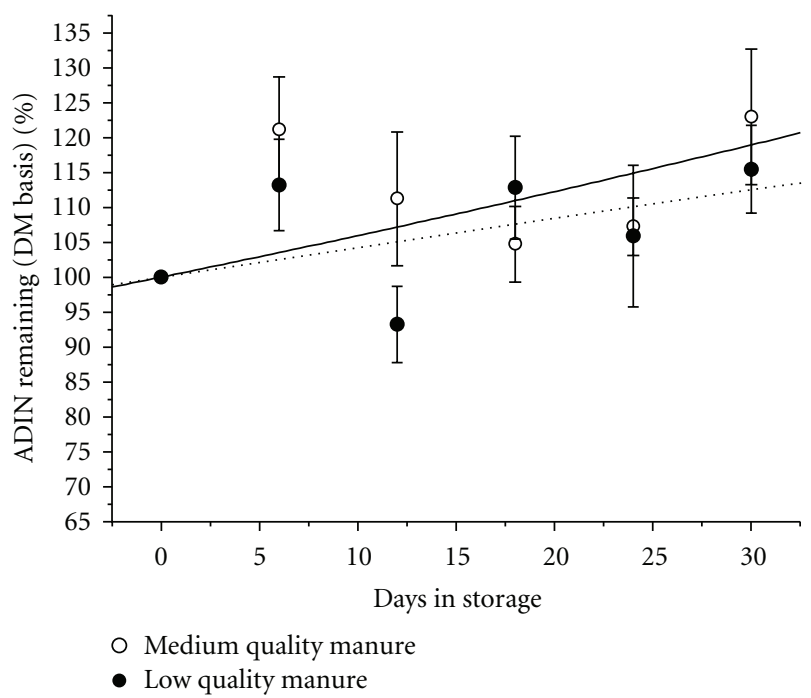

(c)

Figure 5: Total organic N, neutral detergent insoluble N (NDIN), and acid detergent insoluble N (ADIN) dynamics in manure in the rainy season experiment (DM basis). Error bars represent standard error of means. Continuous lines represent regression equations for organic $\mathrm{N}$ dynamics in manure during the rainy season experiment. Solid lines (-) represent the best fit regression lines for Medium quality manure treatments. Dashed lines (- - -) represent the best fit regression lines for Low quality manure treatments. $Y$ represents the amount of organic N, NDIN, or ADIN remaining in the manure (\% of initial content, DM basis). (a) Total organic N dynamics (\%N, DM basis). Medium quality manure: $Y=100 e^{0.00174 x}, R^{2}=0.989$. Low quality manure: $Y=100 e^{0.00576 x}, R^{2}=0.986$. The rate equations for organic $\mathrm{N}$ dynamics between the two manure sources did not differ at significance level $\alpha=0.05$. (b) Neutral detergent insoluble N dynamics (\%NDIN, DM basis). Medium quality manure: $Y=100 e^{0.00478 x}, R^{2}=0.984$. Low quality manure: $Y=100 e^{0.0112 x}, R^{2}=0.973$. The rate equations for NDIN dynamics between the two treatments did not differ at significance level $\alpha=0.05$. (c) Acid detergent insoluble $\mathrm{N}$ dynamics (\%ADIN, DM basis). Medium quality manure: $Y=100 e^{0.00578 x}, R^{2}=0.974$. Low quality manure: $Y=100 e^{0.00394 x}, R^{2}=0.973$. The rate equations for ADIN dynamics between the two treatments did not differ at significance level $\alpha=0.05$.

The presence of urine lowered the fiber-bound $\mathrm{N}$ content of the manure in storage. After 120 days of storage during the dry season experiment, the Medium quality manure alone contained $4.9 \%$ NDIN, and 3.9\% ADIN (DM basis). Urineamended Medium quality manure contained 3.9\% NDIN, and $3.2 \%$ ADIN (DM basis). At the end of the dry season experiment, the Low quality manure alone contained $6.2 \%$
NDIN, and 5.2\% ADIN (DM basis). Low quality manure containing urine contained 5.0\% NDIN, and $4.1 \%$ ADIN. At the end of the dry season experiment, the Low quality manure contained more NDIN and ADIN than the medium manure $(P<0.02$ and $P<0.03$, resp.). The average organic $\mathrm{N}$ content of manure after 120 days of storage was 8.6\% (DM basis). Manure from both sources without urine contained 


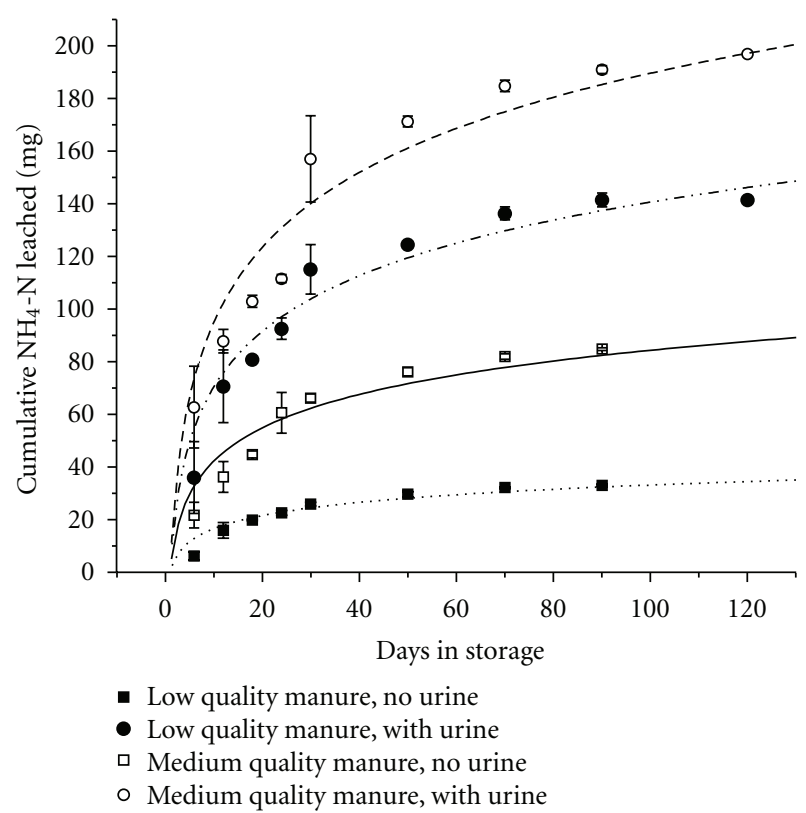

Figure 6: Cumulative $\mathrm{NH}_{4}-\mathrm{N}$ (mg $\mathrm{NH}_{4}-\mathrm{N}$ per manure storage unit) leached from manure of the dry season storage experiment. Error bars represent standard error of the mean values. Continuous lines represent best-fit regression equations for cumulative $\mathrm{NH}_{4}$ $\mathrm{N}$ (mg) leached from manure during the dry season experiment. The solid line (-) represents the Medium quality manure, no urine treatment. The dashed line (---) represents the urineamended Medium quality manure treatment. The dotted line $(\ldots)$ represents the Low quality manure, no urine treatment. The dot-dash line $(-\cdots .$.$) represents the urine-amended Low$ quality manure treatment. $Y$ represents the cumulative $\mathrm{NH}_{4}-\mathrm{N}$ (mg) leached from the manure. Medium quality manure, no urine: $Y=18.3144 \ln (x), R^{2}=0.989$. Medium quality manure, with urine: $Y=41.1785 \ln (x), R^{2}=0.993$. Low quality manure, no urine: $Y=7.1964 \ln (x), R^{2}=0.988$. Low quality manure, with urine: $Y=30.5345 \ln (x), R^{2}=0.994$. The rate equations for leachate $\mathrm{NH}_{4}-\mathrm{N}$ between the four treatments did not differ at significance level $\alpha=0.05$.

more NDIN at the end of 120 days than did the urine treatments $(P<0.05)$. While the time in storage did have an effect on the organic N, ADIN, and NDIN contents of the dry season manure over the entire experiment $(P<$ 0.0001, Table 1), total organic $\mathrm{N}$ and ADIN did not differ between the treatments after 120 days in storage $(\alpha=0.05)$. Exponential decay models with one exponential term were developed for total N, NDIN, and ADIN dynamics in manure (Figures 4(a)-4(c)). Exponential regression with two terms to describe total N, NDIN, and ADIN dynamics in manure failed to converge.

Logarithmic regression using equations with two terms to describe $\mathrm{NH}_{4}-\mathrm{N}$ leaching losses did not converge. Cumulative leaching of $\mathrm{NH}_{4}-\mathrm{N}$ from manure in the dry season experiment is described by the single-term logarithmic rate equations in Figure 6. The presence of urine had a significant positive effect on the amount of $\mathrm{NH}_{4}-\mathrm{N}$ leached from manure in the dry season experiment $(P<0.02$, Table 3$)$. In total, the urine-amended manure units lost an average of

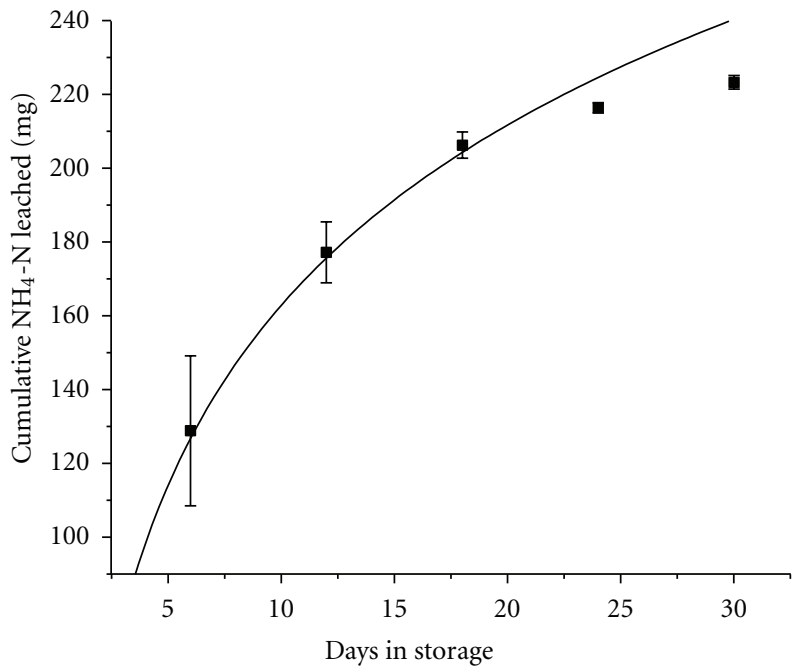

FIgure 7: Cumulative $\mathrm{NH}_{4}-\mathrm{N}$ (mg $\mathrm{NH}_{4}-\mathrm{N}$ per manure storage unit) leached from manure of the rainy season storage experiment. Error bars represent standard error of the mean values. The continuous line represents best-fit regression equations for cumulative $\mathrm{NH}_{4}-\mathrm{N}$ (mg) leached from manure during the dry season experiment. $X$ represents the number of days in storage. The solid line represents all treatments. $Y$ represents the cumulative $\mathrm{NH}_{4}-\mathrm{N}$ $(\mathrm{mg})$ leached from the manure. All treatments: $Y=70.7127 \ln (x)$, $R^{2}=0.998$.

$199 \mathrm{mg} \mathrm{NH}_{4}-\mathrm{N}$ while storage units containing only manure lost an average of $104 \mathrm{mg} \mathrm{NH}_{4}-\mathrm{N}$ over 120 days of storage. These cumulative leaching losses represents up to $26 \%$ of the initial manure $\mathrm{NH}_{4}-\mathrm{N}$ from urine-amended manure and up to $61 \%$ of the initial manure $\mathrm{NH}_{4}-\mathrm{N}$ from manure alone. The source of the manure, low farm or medium farm, had no effect on $\mathrm{NH}_{4}-\mathrm{N}$ leaching rates $(\alpha=0.05$, Table 3$)$.

\section{Discussion}

The 14\% greater loss of mass from urine-amended manure observed in this study, a loss of $0.6 \mathrm{~kg}$ manure DM in urineamended manure and $0.5 \mathrm{~kg}$ manure DM from manure alone, was a larger difference than expected. The observation supports the perception of smallholder farmers that urine speeds up the decomposition of manure in storage [1]. In previous studies of composted manure, the manure lost mass over time due to the mineralization of nutrients and other degradation processes that cause structural disintegration [19]. In this study, mass loss was observed. The manure continued to lose solid mass after 30 days of storage as a result of microbial activity. Farmers may find the faster degradation of urine-amended manure unacceptable because it results in a smaller volume of manure available to apply to the soil at planting. However, urine may increase the rate of decomposition of the feed refusals in manure, thereby lowering the $\mathrm{C}: \mathrm{N}$ ratio of the manure and lowering the risk of $\mathrm{N}$ immobilization when manure is applied to soil.

The results partially support the hypothesis that most $\mathrm{N}$ losses from stored manure occur within the first month of storage. In the dry season and rainy season experiments, 
$\mathrm{NH}_{4}-\mathrm{N}$ losses were large during the first 30 days of storage. In both experiments, the pools of total organic $\mathrm{N}$, the more degradable hemicellulose-bound $\mathrm{N}$, and the refractory fiberbound and lignin bound $\mathrm{N}$ had increased in content by the end of the storage period (Figures $4(a)-4(c)$ and 5(a)-5(c)). The increase in the recalcitrant $\mathrm{N}$ fractions is probably due to manure mass loss: as the manure loses mass over time, the concentration of the recalcitrant $\mathrm{N}$ fractions inflates [18].

Although some low molecular weight organic-N compounds may have escaped the system via the leachate, the bulk of the loss of the available $\mathrm{N}$ is due to the mineralization activities by microbes. The labile organic $\mathrm{N}$ remaining in the manure after 30 days is likely of microbial origin. The ADIN that remains, $5.1 \%$ of manure DM in the rainy experiment, likely is either part of the lignin fraction or indigestible components of microbial cell walls. The ADIN is very slowly mineralized by microbes $[16,17]$.

The hypothesis that manure containing urine would have more $\mathrm{NH}_{4}-\mathrm{N}$ and less fiber- $\mathrm{N}$ and lignin- $\mathrm{N}$ than manure without urine was only partly upheld by the results of this study. In the dry season, the results were as expected. The presence of urine significantly decreased the organic $\mathrm{N}$ content in the manure. This effect may be due to the urine providing the microbes with a larger pool of $\mathrm{NH}_{4}$ $\mathrm{N}$ for metabolism and growth than the $\mathrm{NH}_{4}-\mathrm{N}$ pool in the manure solution alone. The less $\mathrm{N}$-constrained environment of urine-amended manure supports larger bacterial populations than that of manure alone, so the microbial degradation of refractory manure compounds is more rapid when urine is present in the manure mixture. The results of another study of stockpiled manure on small Kenyan farms indicated that urine, when added to manure, had no effect on the nutrient composition of the manure [2]. This result may have occurred because the manure piles sampled in the study differed in age or because the urinary $\mathrm{N}$ was lost to volatilization before being mixed with manure. The manure came from actual manure storage units on many small farms in central Kenya, and manure age was not controlled [2].

Urine may also boost the mineralization of organic $\mathrm{N}$, thereby lowering the total organic $\mathrm{N}$ content of the manure, by increasing the water content of the manure. This effect was observed in this study, with urine amendments producing manure with less fiber- and lignin-bound $\mathrm{N}$ than manure with no amendments (Figures 4 (b) and 4(c)). The wetter environment and increased saturation of the manure may allow microbes easier access to sites where organic $\mathrm{N}$ is present. Also, solubilization of OM may be facilitated in the more saturated system. Dissolved organic matter (OM) is more easily degraded by microorganisms than solid OM [20]. The failure of urine to significantly affect the organic $\mathrm{N}$ composition of the manure in the rainy season experiment may be due to the fact that the heavy rainfall resulted in urine-amended and nonamended manure with similar water contents, so that any difference between the treatments was obscured (Figures 4(a)-4(c) and 5(a)-5(c)).

The hypothesis that the presence of urine in stored manure would leach a greater volume of leachate with a higher content of $\mathrm{NH}_{4}-\mathrm{N}$ than manure without urine was supported in the rainy season experiment. Urine did increase the
$\mathrm{NH}_{4}-\mathrm{N}$ content of the leachate in both the dry season and rainy season experiments. These results suggest measures to prevent leaching losses, such as sheltering the manure from rain and creating a leachate catchment system in which the leachate is collected and returned to the manure pile, should be taken for urine-rich manure in order to conserve manure $\mathrm{NH}_{4}-\mathrm{N}$.

The hypothesis that rainfall increases $\mathrm{N}$ losses from manure via leaching was not supported by the data for the urineamended manure. Total $\mathrm{NH}_{4}-\mathrm{N}$ losses from urine-amended manure in the rainy season experiment were $100 \mathrm{mg}$ more (1.5 times greater) than the amount lost from urineamended manure in the dry season experiment. However, as a percentage of the initial manure $\mathrm{NH}_{4}-\mathrm{N}$ concentration, the urine-amended manure in the dry season lost more $\mathrm{NH}_{4}-\mathrm{N}$ than in the rainy season: a loss of $26 \%$ of the initial $\mathrm{NH}_{4}$ $\mathrm{N}$ in the dry season experiment versus a $12 \%$ loss of the initial $\mathrm{NH}_{4}-\mathrm{N}$ in the rainy season experiment. Heavy rainfall increased the volume of the leachate, and the $\mathrm{NH}_{4}-\mathrm{N}$ content decreased accordingly for the no urine treatments. In spite of this result, the loss of $337 \mathrm{mg} \mathrm{NH} \mathrm{NH}_{4}-\mathrm{N}$ from urine-amended manure observed in the rainy experiment is an $\mathrm{N}$ loss that should be prevented in order to conserve manure $\mathrm{N}$.

\section{Conclusions}

The results suggest the need to protect manure from rain to prevent leaching $\mathrm{N}$ losses. Collecting the leachate as it escapes the manure in storage and pouring it back onto the manure would be another way to conserve manure N. If manure is piled on a downhill slope immediately adjacent to fields that require fertilizing, the $\mathrm{N}$-rich leachate may drain into the soil of those fields. If plastic sheeting, an affordable and readily available commodity in Kenya, is first placed on the ground and manure piled on top of it, more of the leachate would drain onto the field. Plastic sheeting could also be used to collect leachate to return to the manure. Contamination of drinking water by uncontrolled leachate runoff and seepage into soil can also be avoided by the use of plastic sheeting. A limitation of using plastic sheeting to collect leachate is the potential for large $\mathrm{N}$ losses from the leachate via $\mathrm{NH}_{3}$ volatilization when the leachate is exposed to air. Covering stored manure using plastic sheeting or another material impervious to rainfall may conserve manure $\mathrm{N}$ by preventing leaching losses.

Manure that remains in storage for many months continues to lose mass because of microbial activity and compacts due to gravity. The result is manure with far less $\mathrm{N}$ than its initial content and less bulk manure to spread on the fields at planting time. To use the manure $\mathrm{N}$ before it is lost via leaching, it is recommended that manure not be stored more than 30 days. If the manure cannot be applied to major crops such as maize during the growing seasons, it might be applied to the kitchen gardens. These gardens often contain vegetables that provide important vitamins and minerals to the diets of farm residents. Selling manure to neighboring farms would generate income but could exacerbate the negative nutrient balances observed on most of the farms in the Kenyan highlands. 


\section{Abbreviations}

OM: Organic matter

NDIN: Neutral detergent insoluble N

ADIN: Acid detergent insoluble N.

\section{Acknowledgments}

The authors would like to thank The World Agroforestry Centre (ICRAF) and staff, the Kenya Agricultural Research Institute and staff, the Bradfield Award at Cornell University, the Cornell Center for the Environment Graduate Research Award, Dr. James B. Robertson, and Dr. Stephen Njoka.

\section{References}

[1] J. K. Lekasi, J. C. Tanner, S. K. Kimani, and P. J. C. Harris, "High potential production system portfolio of the natural resources systems programme renewable natural resources knowledge strategy department for international development. ryton-on-dunsmore," in Manure Management in the Kenya Highlands: Practices and Potential, The Henry Doubleday Research Association (HDRA), Coventry, UK, 2nd edition, 2001.

[2] J. K. Lekasi, J. C. Tanner, S. K. Kimani, and P. J. C. Harris, "Cattle manure quality in maragua district, central kenya: effect of management practices and development of simple methods of assessment," Agriculture, Ecosystems and Environment, vol. 94, no. 3, pp. 289-298, 2003.

[3] M. C. Rufino, E. C. Rowe, R. J. Delve, and K. E. Giller, "Nitrogen cycling efficiencies through resource-poor African croplivestock systems," Agriculture, Ecosystems and Environment, vol. 112, no. 4, pp. 261-282, 2006.

[4] M. K. Luebbe, G. E. Erickson, T. J. Klopfenstein, and M. A. Greenquist, "Aerobic composting or anaerobic stockpiling of feedlot manure. Nebraska Beef Cattle Reports," 2008, http://digitalcommons.unl.edu/animalscinbcr/25/.

[5] S. Tamminga, "Nutrition management of dairy cows as a contribution to pollution control," Journal of Dairy Science, vol. 75, pp. 345-357, 1992.

[6] H. K. Murwira, M. J. Swift, and P. G. H. Frost, "Animalsoil interactions: manure as a key resource in sustainable agriculture. livestock and sustainable nutrient cycling in mixed farming systems of sub-saharan africa. Vol. II: technical papers," in Proceedings of an International Conference, J. M. Powell, S. Fernandez-Rivera, T. O. Williams, and C. Renard, Eds., pp. 131-148, International Livestock Centre for Africa, Addis Ababa, Ethiopia, November 1993.

[7] J. C. Marini and M. E. Van Amburgh, "Nitrogen metabolism and recycling in Holstein heifers," Journal of Animal Science, vol. 81, no. 2, pp. 545-552, 2003.

[8] H. M. van Es, C. P. Gomes, M. Sellmann, and C. L. van Es, "Spatially-balanced complete block designs for field experiments," Geoderma, vol. 140, no. 4, pp. 346-352, 2007.

[9] J. E. Vercoe, "Breed and nutritional effects on the composition of faeces, urine, and plasma from Hereford and Brahman $\mathrm{x}$ Hereford steers fed on high and low quality diets," Australian Journal of Agricultural Research, vol. 18, pp. 1003-1013, 1967.

[10] A. L. Chaney and E. P. Marbach, "Modified reagents for determination of urea and ammonia," Clinical Chemistry, vol. 8, no. 2, pp. 130-132, 1962.

[11] AOAC, "Protein (crude) in animal feed, forage (plant tissue), grain, and oilseeds," Official Methods of Analysis of the
Association of Official Analytical Chemists 954.01, AOAC, Gaithersburg, Md, USA, 2000.

[12] G. Licitra, T. M. Hernandez, and P. J. Van Soest, "Standardization of procedures for nitrogen fractionation of ruminant feeds," Animal Feed Science and Technology, vol. 57, no. 4, pp. 347-358, 1996.

[13] SAS Institute Inc (v 9.1), SAS software, Version 9.1.3 of the SAS System for Windows. SAS and all other SAS Institute Inc. product or service names are registered trademarks or trademarks of SAS Institute Inc. Cary, NC, USA, SAS Institute Inc.

[14] R. E. Muck and B. K. Richards, "Losses of manurial nitrogen in free-stall barns," Agricultural Wastes, vol. 7, no. 2, pp. 65-79, 1983.

[15] D. W. Bussink and O. Oenema, "Ammonia volatilization from dairy farming systems in temperate areas: a review," Nutrient Cycling in Agroecosystems, vol. 51, no. 1, pp. 19-33, 1998.

[16] T. K. Kirk, W. J. Connors, and R. D. Bleam, "Preparation and microbial decomposition of synthetic $\left[{ }^{14} \mathrm{C}\right]$ lignins," Proceedings of the National Academy of Sciences of the United States of America, vol. 72, no. 7, pp. 2515-2519, 1975.

[17] D. L. Crawford and R. L. Crawford, "Microbial degradation of lignocellulose: the lignin component," Applied and Environmental Microbiology, vol. 31, no. 5, pp. 714-717, 1976.

[18] O. Martins and T. Dewes, "Loss of nitrogenous compounds during composting of animal wastes," Bioresource Technology, vol. 42, no. 2, pp. 103-111, 1992.

[19] D. B. Dresbøll, J. Magid, and K. Thorup-Kristensen, "Longterm stability and mineralization rate of compost is influenced by timing of nutrient application during composting of plant residues," Compost Science and Utilization, vol. 14, no. 3, pp. 215-221, 2006.

[20] D. Said-Pullicino and G. Gigliotti, "Oxidative biodegradation of dissolved organic matter during composting," Chemosphere, vol. 68, no. 6, pp. 1030-1040, 2007. 


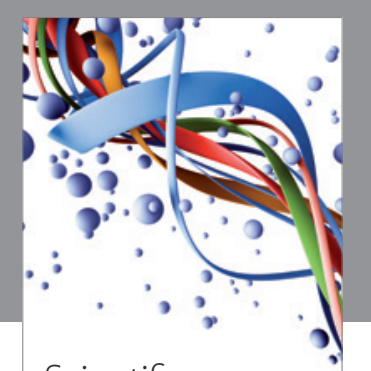

Scientifica
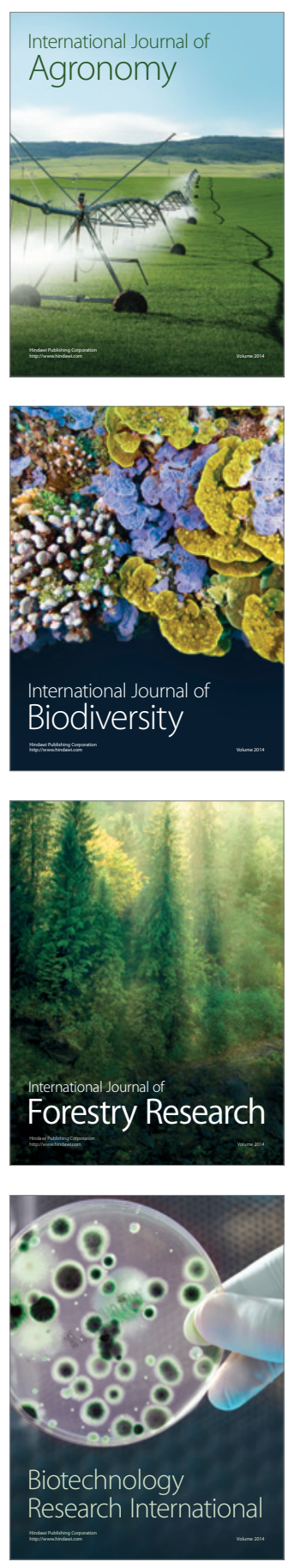
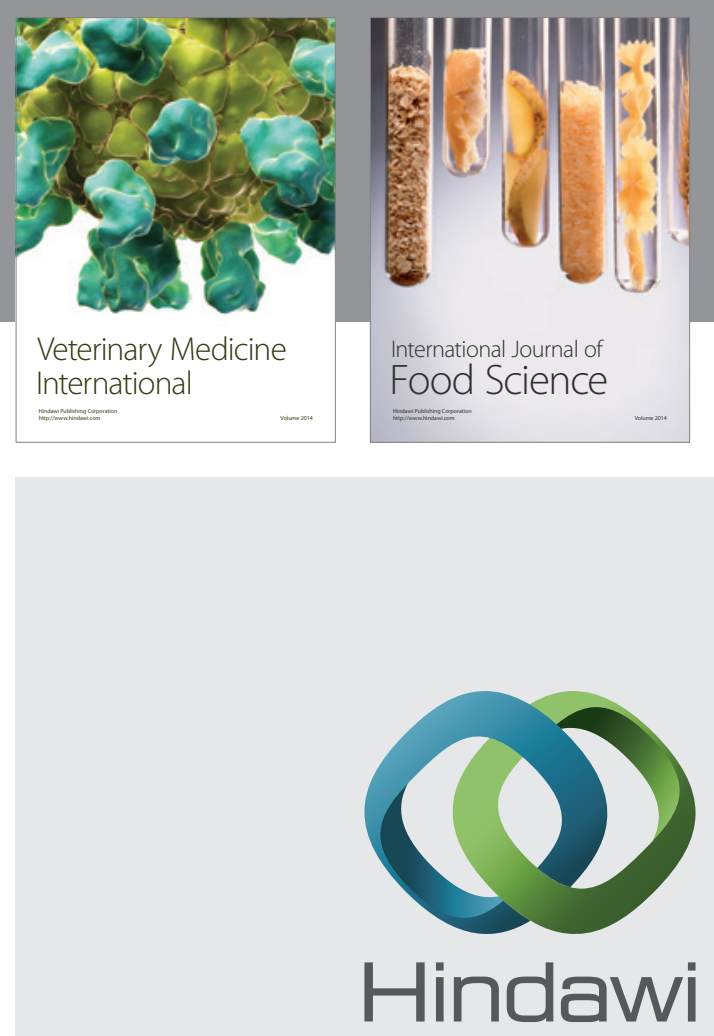

Submit your manuscripts at

http://www.hindawi.com
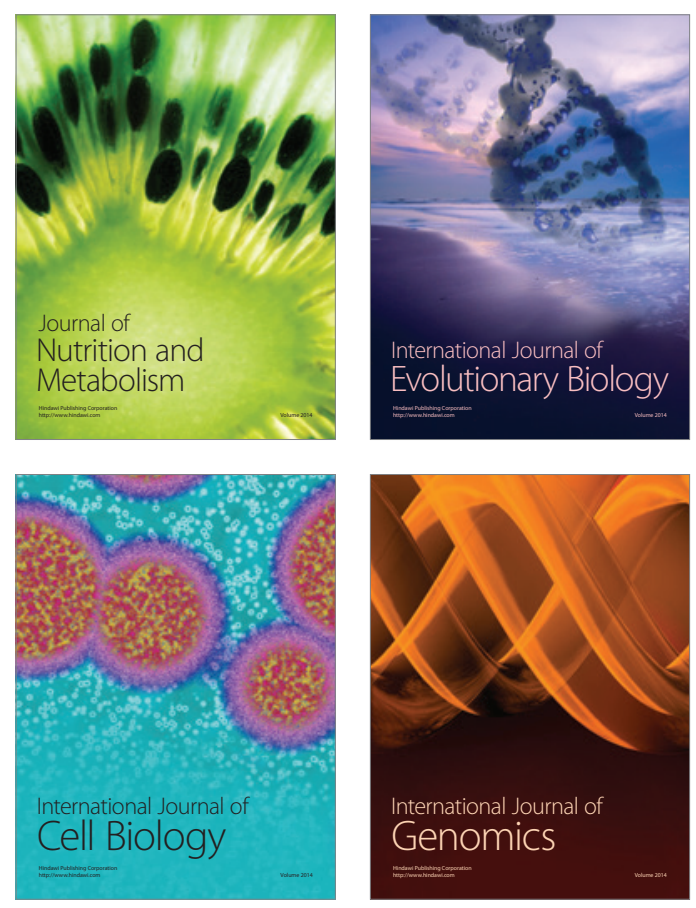
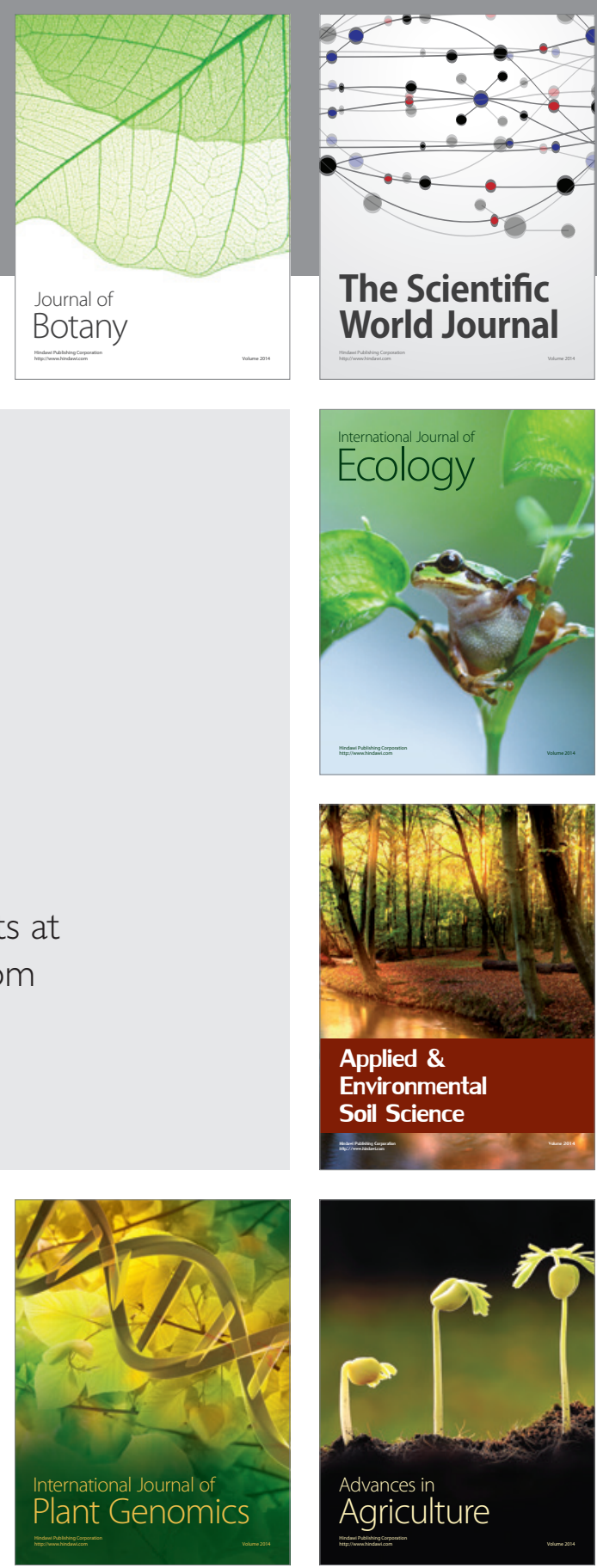

The Scientific World Journal
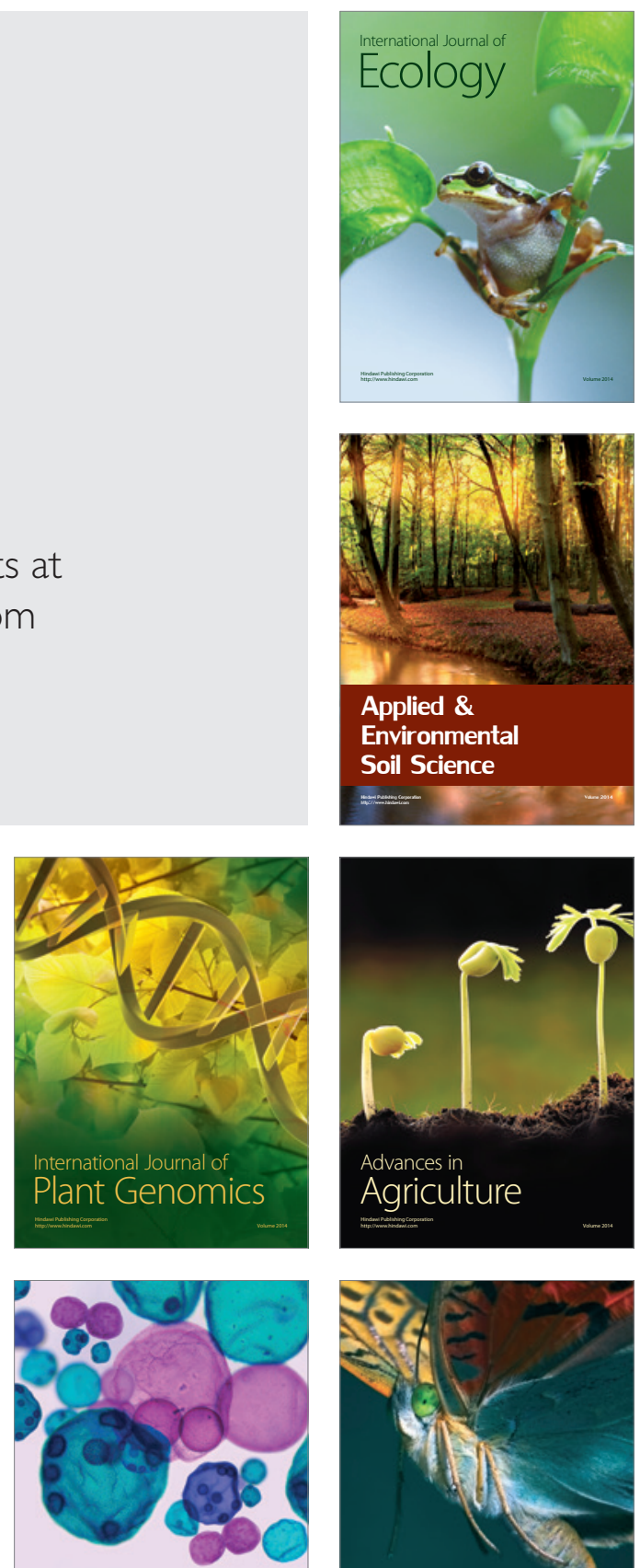

International Journal of Microbiology

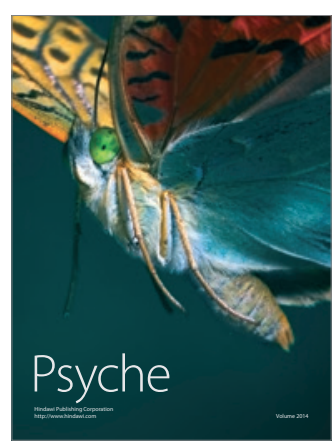

